UDC 339.1: 658.87

JEL Classification: M 2, M 31

\author{
Alona O. Natorina \\ PhD (Economics), Head of the Educational Establishments Sector \\ Higher Education Statistics and Analysis Department \\ SSI «Institute of Educational Analytics» (Kyiv, Ukraine)
}

\title{
ACTIVITY OF RETAILERS AND FMCG PRODUCERS IN THE DIGITAL AGE
}

Based on the fundamental results of research, the activity of retailers and FMCG producers in the conditions of the digital era is investigated and analyzed. The directions of significant influence on consumer behavior are identified; and the key aspects of retailers' activities, which allow maximizing meet consumer preferences and influence on their behavior, are interpreted. The prioritized FMCG producers' areas of activity in the market are determined. Considering intensive competition between retailers and FMCG producers, the relevant recommendations for their effective market functioning, realization of an active marketing policy and the effective strategic solutions implementation are formulated.

Key words: traditional retailers, digital retailers, FMCG producers, consumer preferences, consumer behavior.

\section{DOI: 10.15276/mdt.2.2.2018.6}

Statement of the problem in general form and it's connection with important scientific or practical tasks. Today's consumers have strong needs for immediate satisfaction. This trend is spread around the world as technology evolves and becomes more readily available, and as emerging countries grow economically. Retailers and FMCG producers are faced with the challenge of competing for consumers' time and disposable income. In such conditions, each market participant, including retailers and FMCG producers, needs to constantly monitor consumer preferences and maximize their satisfaction, as well as rationally choose directions for their activities for the future.

Analysis of the latest research and publications, which initiated the solution of this problem and on which the author relies. Theoretical and practical aspects of the retailers' activity in digital economy are studied by well-known scientists and economists: Davidaviciene V., Hitoshi S., Hoogenber M., Kesteloo M., Masayuki A., Oklander M., Rogers D., Sabaityte J., Samuely A., Schmitt B., Thau B. Despite this fact, the issue of effective simultaneous functioning of traditional retailers, digital retailers and FMCG producers has not been studied yet in detail.

Formulation of the purpose of the article (statement of the problem). The aim of the article is to investigate and analyze the activities of retailers and FMCG producers in a digital age using the results of thorough research, as well as give practical guidance for the successful retailers and FMCG producers functioning in the market.

Statement of the main material of the research with full justification of the scientific results obtained. According to [1] consumers' perception and consumption patterns have changed a lot in the digital age. As new purchase desires and demands are created, consumers have higher and new demands for the connotation and denotation of goods, consumption scenarios and experience along with consumption upgrade and update, thus consumption demands have various new business formats. Accurate understanding of 
consumers' demands is an important premise for enterprises to follow the trend and readjust strategic orientation. In particular, the following four trends are important factors in the diversification of consumer values $[1 ; 5-6]$ :

1. Digital channels and socialized online shopping.

Changes in consumers' shopping behaviors are mainly reflected in digitalized channel and socialized online shopping. Firstly, the prevalence of Internet and electronic devices makes the information screening in early stage easier for consumers. Consumers continue to spend more time on obtaining product information in the multi-channel environment, and large numbers of customers spend 90 percent time to browse products for a comprehensive research before purchasing. Therefore, the new digital environment contributes to consumer behaviors centered on knowing information related to brands and products. Deloitte research results [5] show that consumers' cost on «digital life» increases significantly.

Online shopping has huge potential in socialized media / social networks and socialized online shopping will become a future trend. Socialized shopping behaviors at consumption end reflect to a certain extent the application form of emerging community economy in the retail industry. Consumers joining in the same community for similar hobbies, identities and labels tend to have deep sense of identity and common languages in values and aesthetic, and similarities in consumption behaviors and purchase intention. In a stable community established either in a consciously or unconsciously way, an interaction closedloop is built among consumers for them to obtain information and spread it based on nodes. Reputation-based quality contents are widely spread for many times and thus creating unique sharing contents.

2. Quality-oriented purchase and experience-based consumption.

Customers' consumption concept also changes dramatically. Firstly, changes in consumption concept arise from improved purchasing power and changes in major consumer groups. The new generation of customers grow up in a better economic environment with better economic conditions; therefore, they know how to value quality more. That is why consumption concept will gradually transform from price-driven to quality and consumption experience-oriented.

The range of choices for products and services will further expand and consumers will have a greater tendency to prioritizing not only physical value and price, but also a broad variety of other factors. To understand these other factors, it is useful to consider the five strategic experiential modules defined by Bernd H. Schmitt (2011) [7]. Experiential value refers to sensory value arising when people feel satisfied or moved through the experience of using a product or service, and its concept goes beyond the traditional sense of physical or monetary value. These five components are: 1) sense (engages the five human senses of sight, sound, smell, taste and touch); 2) feel (creates positive emotional experiences); 3) think (appeals to our intellect and creative thinking); 4) act (invokes changes in our behavior and lifestyle); 5) relate (draws upon our innate search for belonging and meaning). Providing experiential value associated with these five components is expected to become increasingly important. One of the characteristics of consumers emphasizing experiential value is that consumers are meticulous about not only the products and services themselves, but also their design and purchase process.

As pointed out in Masayuki, A. \& Hitoshi, S. report (2014) [6] an important change in consumer attitudes is the trend toward the desire to be active co-creators instead of simply consumers. Another trend pointed out in the report is that consumers want to transform the design, provision, sales, and purchase of goods and services to their preferences. These consumers value their own personal scenarios linked to products and want to be attracted to brand-name products without being constrained by the brands. What is necessary to provide 
value to such consumers is to encourage them to participate at various stages from design to purchase. Concrete examples include consumer participation in product development activities (user innovation), and sales activities related to used product markets and transactions.

3. Personalized consumption and mobile payment. Focus on safety and security.

The emotional connotation and identities carried by goods are additional decisive factors when consumers selecting goods. In general, they prefer to buy personalized and niche goods, seek for the recognition of sub-cultural communities, and share shopping experience on social media. Besides, consumers are becoming gradually mature in understanding and accepting personalized products. To satisfy personalized requirements, consumers are not averse to compromising on price to some extent.

Consumers' open views on personalization, that Figure 1 illustrated, make consumers participate in design and producing process of products more actively.

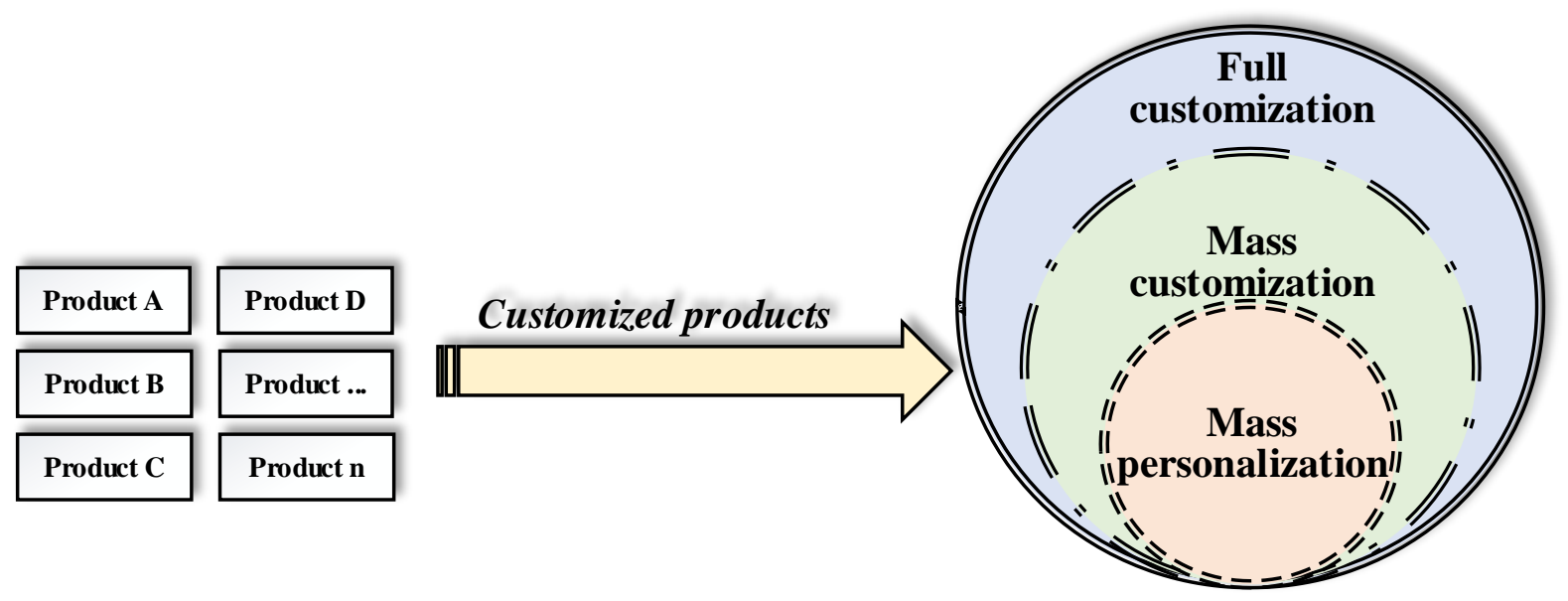

Figure 1 - Customization of products in the market [1]

As digital mobile technology advances, consumers are rediscovering the importance of human connections and have begun emphasizing customer service experiences at brick-andmortar stores and e-commerce websites [6]. Trust is essential for retailers seeking to harness data about consumers in order to provide a better experience. Trust also plays an important role in how consumers evaluate online security risks. The PwC (Global Consumer Insights Survey, 2018) [8] asked respondents how they reduce the risk of online security issues and fraud (allowing them to select all the options that apply). Figure 2 demonstrated all results of the survey.

So more than half consumers said that they only use credible and legitimate websites $(57 \%)$ or choose providers they trust when making payments $(51 \%)$. Other factors, such as minimizing the amount of data given out and avoiding the use of artificial intelligence devices, trailed far behind. It is notable that overall consumers' security precautions seem to have decreased slightly since survey [4] in 2017 year. This could mean that consumers trust retailers more, which would be good news, and at the same time, it may imply raise expectations for reliable security [8-9].

While consumer trust can be the key to a company's success, the coveted prize is to win consumers loyalty. Ideally, these consumers not only develop an allegiance to a company, but they also become brand ambassadors, encouraging others to follow suit. Given the nature of online shopping, where consumers are buying products sight unseen, providing personal 
data online, and often paying in advance, having a brand and website that consumers trust is critical. Competitive prices or delivery options can be a deciding factor when potential customers are choosing a vendor, but at the end of the day, consumers will only buy from websites they trust. Therefore, when shopping in-store, consumers have certain service level expectations of staff attentiveness or product knowledge. In an online environment, however, most transactions are conducted with no personal contact or service at all [10].

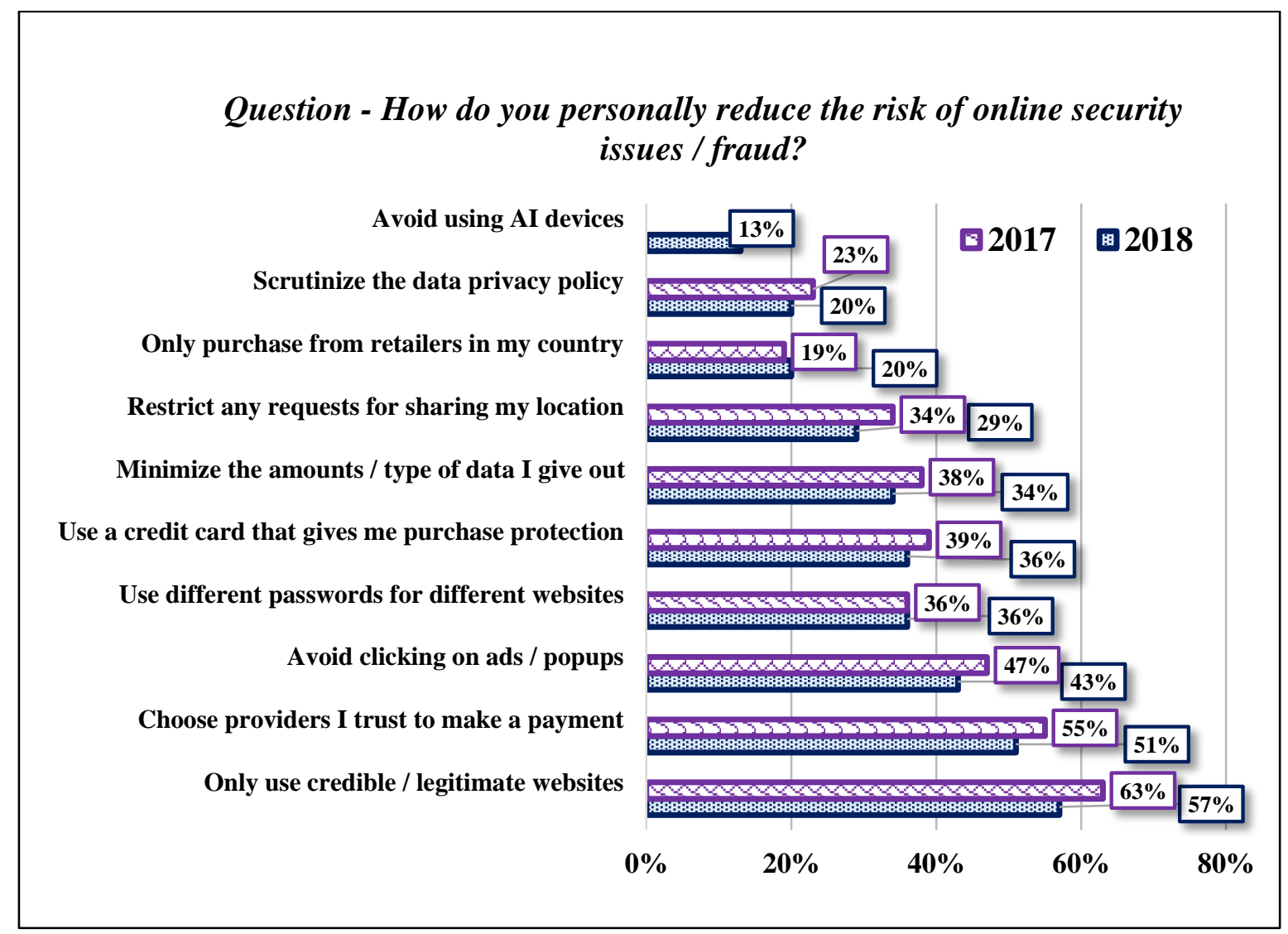

Figure 2 - Results of a consumers' survey regarding online risks [9]

Providing excellent consumer online support, loyalty programs and benefits, and a forum for feedback, will all remain vital to earning the loyalty of customers across generations. However, in order to attract the younger consumers, companies need to offer more personalized interactions, more customized experiences and engagement. To win and retain online customers, companies need to find cost-effective ways of providing the service and quality that customers expect, while keeping prices competitive. Consumers, depending largely on their country, culture or age, as well as on the type of product being purchased, will each be more or less willing to trade-off service or quality for price [8-10].

The retailers that are able to identify and segment their target customers based on these factors, and develop product offerings and online strategies that are distinctly tailored for each unique market, will be truly poised to succeed in the online revolution. Therefore, retailers should properly understand the importance of consumers' back-to-basics preferences and take appropriate measures. With changes occurring in technology and lifestyle, consumers' attitude toward time has significantly changed. A survey about consumer trends [6] showed that $50 \%$ of the world's consumers want timesaving products and services. 
Today's consumers have strong needs for immediate satisfaction. These trends are expected to spread around the world as technology evolves and becomes more readily available, and as emerging countries grow economically. Retailers are faced with the challenge of competing for consumers' time and disposable income, rather than participating in large market shares $[6 ; 10]$. Thus, consumer values are becoming increasingly diverse as value chains based on collaborative value creation are emerging on a global scale, driven by consumer market synchronization around the world, the rise of platform businesses and bilateral information flow.

Consumers are increasingly gaining power, and, at the same time, producers are increasing their contact with consumers. Today, having an omni-channel digital retailing strategy is a must the time to discuss its necessity is over. The main existing digital retail trends are interpreted below [6].

Trend 1. Stores are places for experiences and for covering the «last mile».

The movement to redefine retail stores as places for experiences instead of places for shopping is spreading around the world. Offering a place for experiences is not a new role, but reflects a back-to-basics approach for retailers. In other cases, retailers successfully operate websites. As the online market develops, the value of being able to receive orders anywhere at any time is gaining importance [11].

The above trends indicate a shift in the role of retail stores from places for shopping to places for covering the «last mile», and we are heading into an era in which retailers that cannot exhibit originality through their product lines will be unable to survive.

Trend 2. Transformation from vendors to «information providers».

The ability to analyze and disseminate information has already been an important factor for digital retailers, and its importance is expected to continue to grow. As retailers become experience providers, they are expected to increasingly emphasize the use of digital mobile technology for providing information on products and services in order to deliver value to customers.

The key components of differentiated value will be not only the aforementioned experiential value provided in stores, but also the value of guaranteeing product quality and reliability. As mentioned earlier, Specify invests an enormous amount in its distribution networks. If digital retailers consign e-commerce with such extensive infrastructure to distribute products, retailers can concentrate their efforts on differentiating the products and value that they provide. Cooperation in product development is also an important factor. By collaborating with manufacturers as well as e-commerce businesses, retailers can promote product development and user innovation based on the analysis of data on customers' shopping experiences. This enables digital retailers to improve their ability to provide value to customers and is thus an important factor in differentiating their products.

Digital retailing has become an information-based industry. One negative side effect of this trend is risk associated with information security. Strengthening information security systems has now become one of the highest priority issues for retailers and consumer products companies around the world. While focusing on establishing and/or growing a profitable digital retail, traditional retailers and FMCG producers often overlook a looming problem: the liability of a physical store network in the face of shrinking offline sales [12].

Today FMCG producers face to a serious challenge: they must be able to launch new products in the market during a short period. According to the Nielsen State of Innovation survey (2017) [4], 84\% of experts in the field of FMCG said that today it is much more difficult to launch a new product to the market than 5 or 10 years ago, whether it is the achievement of sales growth, adaptation to a new consumer trend or protection of market share. To shorten the duration of the innovation process, producers to «cut corners» - for 
example, spend less time studying consumer feedbacks or ignoring the possibility of improving the concept, which in turn leads to negative results in the market.

Now is the time for FMCG producers to rediscover their roles in response to changes in technology and consumers. The source of value added by companies is expected to shift from manufacturing to the creation of intangibles. In addition, the so-called service-dominant logic, which emphasizes experiential value (generated from, for example, non-product services, purchasing processes and user experience), is expected to become the mainstream in marketing. FMCG producers need to prepare for a new environment in which they must take charge of contact with customers, which has been entrusted to wholesalers and retailers in the past [6].

In the current situation in the market, when FMCG producers and traditional retailers, on the one hand, should launch new products faster, and on the other hand, maintain their high quality and achieve stable market results with them, it is advisable to prioritize four areas of their activity [4]:

A. Permanent tracking of trends over a long period.

In the traditional terms of launching new products, as a rule, there is no time to search for potential «growth points» and new opportunities in the market. This is a significant drawback for producers who want to launch new products quickly, because the search period for an idea can be long and difficult to calculate in advance. This process, as a rule, is the search and aggregation of various data and findings of research from many sources. Moreover, the data is not often structured and coded in the most optimal way for analysis.

Given the need to act faster and therefore with less available information $-77 \%$ of FMCG experts-retailers said that they spend less time than necessary, at least three stages of the innovation process, since speed is the priority. Unfortunately, experience shows that launching new products without processing insights does not lead to sustainable success in the market. It is important to have a clear understanding of what kind of needs the consumer wants to solve when buy a new product, and to collect quality feedback at key stages of the innovation process rather than being guided by assumptions, wishing to speed up the launch.

B. Testing of innovation ideas.

To have the right information on product categories until the beginning of the innovation process allows to correctly ranking the generating product innovation ideas in the long term. Testing is critical in the early stages of the innovation process, when the initial idea is in development and probably has the potential for market success. The opportunity to hear the feedback from consumers about a new idea of creating a product will allow having confidence that the future product will be desirable and necessary for consumers, so the company will invest in the right innovation. Without that, there is a risk to spend years processing an innovation idea that initially has no chance of becoming a successful new product.

C. Concentration on insights and collection of consumer feedbacks.

A high level of primary purchases of a new product is the result of a strong proposal that addresses the needs of consumers; and repeated purchases - this is a consequence, which took place from a positive experience with the product. Traditional retailers and FMCG producers, which meet the needs and exceed expectations, can count on sustainable sales. FMCG producers and traditional retailers have the opportunity to respond to feedback from consumers during the development phase of a new product. Consumer feedback can highlight to skepticism or consumer concerns about the brand promise. Brands and retailers, in turn, have the ability to dispel this skepticism, for example, at the point of sale or through communications, providing a new product with feedback from experts or instructions on how to use the product. Consumer feedbacks can also help improve the perception of the brand and 
the effectiveness of the product usage. The best product experts are consumers who want their needs to be satisfied in the best possible way.

D. Fast optimization of launching a new product.

Trying to launch a new product can be faster - this is not an ideal scenario; However, there are cases when it is not necessary to choose the launch time, and here it is important to have the right tools and information in stock. For example, if a similar competitor's products to enter the market first, it is important to make adjustments on the timing of its launch in order to be sure that a new product will appear on the shelves before consumers form loyalty to the first brand. In addition, the ability to adapt marketing support will help the new product in the event that its sales do not grow at the expected pace - of course, such a plan must be considered before launch. Those that do not use flexible strategies and wait very long to change the timing of launches or optimize them in the current dynamic market situation may face risks. The same companies that can see the correct ideas of new products in the early stages of creating concepts and ensure the correct marketing support and budget for the future product will be one-step ahead. Special attention should be given to identifying the features of the functioning of specialized retailers, as they play a significant role for today's consumers.

According to the results of a global survey of specialized stores organized by Nielsen (September 2016) [4], 90\% of consumers in Ukraine said they were going to make a purchase in a specialized store. The most popular were self-care stores, cosmetics stores and DIY store (Figure 3).

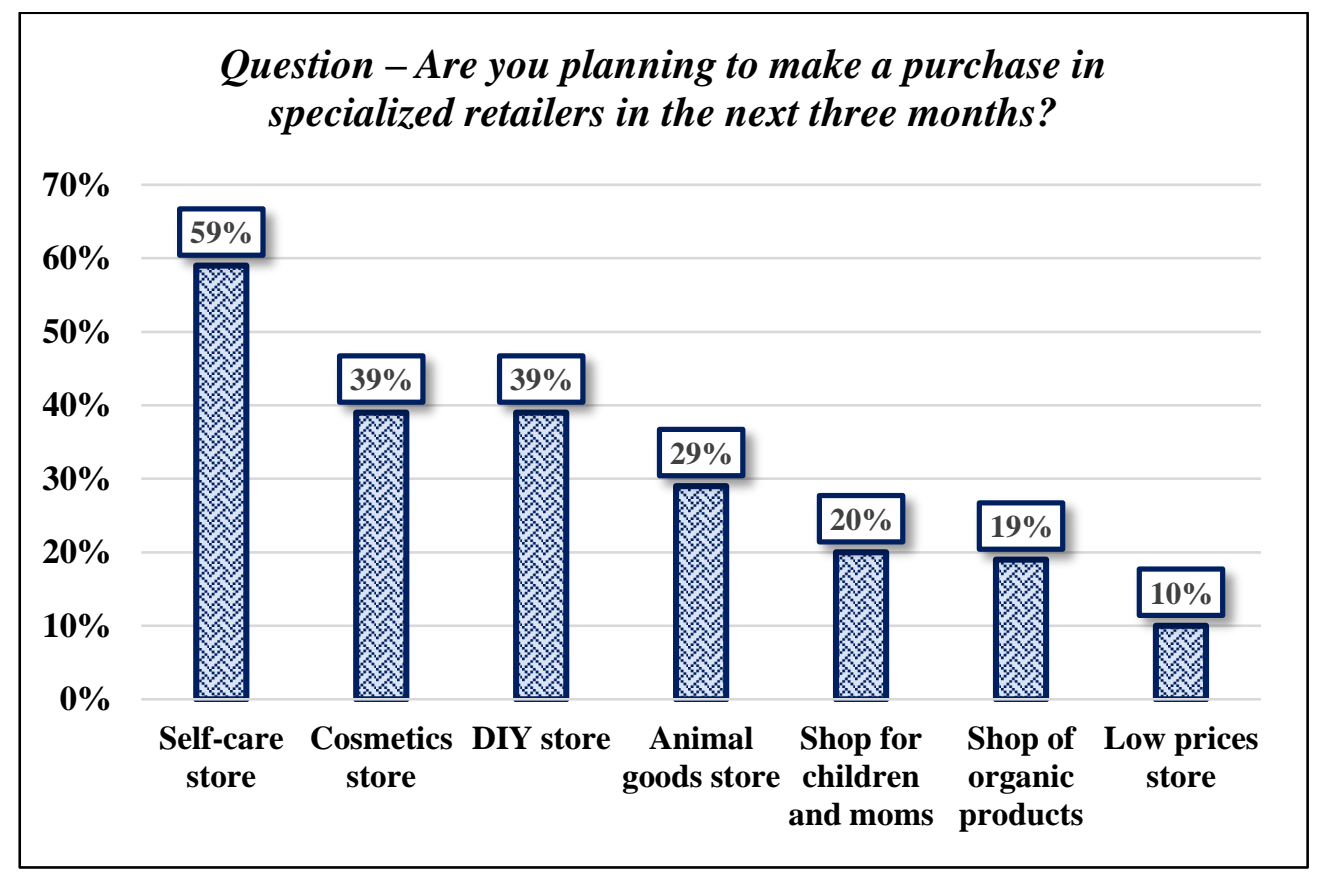

Figure 3 - Results of a consumers' survey regarding purchases in specialized retailers [4]

According to the figure 3, self-care store is the leader among specialized retailers. In order to find out the attitude of consumers to small stores with a specialized assortment, Nielsen in the annual survey [4], found out the share of consumers, that were planning to visit specialized stores in a period of three months and what was the main reason for choosing stores with a limited product range of one type or another.

Despite the fact that buying FMCG by consumers is mainly associated with purchases in large supermarkets and hypermarkets, the small specialized retailers have benefit from a 
number of advantages that are gathered in four main consumer trends based on respondents' answers in the Nielsen Specialty retailer survey [4]:

1. Focus on a specialized assortment. Specialized retailers do not allow buyers to purchase all goods that are available in hyper- and supermarkets. However, the assortment of goods in specialized retailers is satisfied buyer within a certain category. A wide choice of brands or products inside the category compensates for the lack of a wide universal range. $62 \%$ of world consumers and $51 \%$ of Ukrainian consumers choose a specialized store, because they can find the brand or product they need in the store. New products should be given special attention. 59\% of consumers in the world and 39\% in Ukraine claim that they can find new products in the categories they need only in specialized retail.

2. Buying experience - are unique impressions inside the store that will raise the process of making purchases above what was ever before. Efforts from retailers should include consumer service and the atmosphere in the store as a whole. More than half $(62 \%)$ of consumers in Ukraine believe that consumer service in specialized retail is better than in other stores. At the same time, $65 \%$ of Ukrainians are willing to pay more for the best experience in the store, and $65 \%$ of Ukrainians are willing to spend time and go around several retailers to find and get the best buying experience. For $58 \%$ of consumers in Ukraine and for $59 \%$ in the world, the design and atmosphere in a specialized retail seems to be better than in a traditional.

3. Price and quality - an integral part of the goods of any store and specialized retail is no exception. $51 \%$ of Ukrainian consumers and $61 \%$ of consumers in the world agree that the goods in specialized retailers are more expensive than in others. At the same time, half of those surveyed in Ukraine $(59 \%)$ believe that specialized retailers often offer discounted products and special offers. $50 \%$ of respondents in Ukraine believe that the main advantage of goods in specialized stores is quality, which is better than in other stores.

4. Personalization. Protecting personalized data has become a part of the business strategy of all retailers. Retailers offer special personalized offers through loyalty programs $57 \%$ of Ukrainian respondents agree that retailers offer attractive promotions and vouchers as part of loyalty programs compared to other stores. Thus, specialized retailers are popular among consumers and form a separate consumer niche. Despite the fact that a modern buyer is demanding and wants to find everything that he needs in one place, today the key factor for them is a specific product or brand in stores. Consumer will satisfy his unique demand only in a specialized store.

While many retail categories show limited overall sales growth (or even a decline), online sales continues to boom in spite of the economic downturn. Consumer adoption rates are growing as commonly stated barriers to online shopping are starting to disappear. Free delivery and returns are becoming more common. Although currently still mostly used as a marketing tool to stimulate repeat purchase, or as a way to differentiate the customer value proposition from competitors, free delivery and returns will at some point in the future become a standard service for web shops. Even the main consumer barrier of not being able to try or test the product is to some extent alleviated by augmented reality technologies. New service propositions offered by some pure play online retailers, which were primarily meant to remove online shopping barriers, are starting to create barriers for offline shopping. The underlying fundamental problem is that customer flows are shifting. Customers will not only go from offline to online, but also in the «offline world» store, traffic patterns will change. The proper response for retailers is to shrink and adapt their physical store network and make it part of a multi-channel experience [12]. 
To thrive over the next decade, businesses in the traditional retail and FMCG producers will need to develop critical capabilities including a partnership mindset, last-mile delivery and advanced data sciences [13]:

(1) The partnership mindset. Partnerships provide an alternative to the traditional «build or buy» approach to developing capabilities. To meet consumer needs and demands effectively, businesses will have to embed a partnership mindset and culture of collaboration throughout their organizations. In the next decade, partnerships will take a completely new form, as they evolve rapidly and become much more complex. Dynamic, new partnership models, rooted in collaboration, will form across the consumer industries. For future growth opportunities to be realized, an ecosystem will need to develop around the industry. Instead of being rigidly grouped around a specific business or branch of manufacturing, ecosystems will draw together mutually supportive companies from multiple industries that collectively seek to create differentiated offerings and capture value they could not reach alone.

(2) Last-mile delivery. Last-mile delivery will be an industry-wide issue on which businesses will need to work together to solve. An innovative solution would create the optimal combination of cost, efficiency and consumer experience. To achieve this, logistics providers will need to be linked, distribution technologies weaved together, and aggregators or hubs created. Over the next decade, last-mile delivery will need to change.

(3) Advanced data sciences. The future of retail will be built on insights derived from proprietary data - in particular, consumer data. Businesses must act now to reap the rewards of the consumer data gold rush by moving from simply collecting consumer data to using it to support, scale and systematize better decision-making. Recent years have highlighted the importance of leveraging data science as a core capability throughout the organization to drive decision-making, yet it has not been adopted at the rapid rate that the industry requires. Analytics is becoming ever more sophisticated and its use within organizations is proliferating, which makes the speed of capability development crucial for retailers. Advanced analytics drives profits because it provides real-time responses to market shifts and can better inform innovation initiatives.

The primary obstacles preventing retailers from speedily developing these capabilities include the expense of developing an insights-driven organization, a lack of data scientists and the right talent to conduct analytics modelling, and infrastructure gaps that prevent action on the insights generated by predictive analytics. Moreover, consumer relationships have become more difficult than ever to secure and maintain. This makes it imperative for predictive analytics to be applied throughout a retailer's end-to-end value chain and that this capability is continually upgraded to keep pace with industry demands.

Considering the high competition between retailers and FMCG producers, it is recommended for traditional retailers to conduct active marketing policies and implement relevant effective strategic decisions.

As it is mentioned in [12], First, retailers should develop new store formats in different locations, effectively shrinking their average store size. Other channels and media are increasingly fulfilling traditional roles of the store (e.g. getting product advice, doing comparative shopping, trying and testing, and purchasing products). At the same time, the role of the store needs to change in line with evolving shopping behaviors. Retailers have to think beyond traditional size-based format development and management, and instead move to a portfolio of formats based on the purpose of the store in a specific location. We see the following new types of store formats emerging: flagship stores, complementary systems, flexible formats, virtual showrooms, segment concepts and drop-off points.

Second, retailers have to compensate lost offline sales with new online sales providing customers a seamless cross-channel experience. However, it can also be a disadvantage when 
retailers enter the multichannel world with a conservative mindset regarding their physical stores. The belief that the physical stores do not need to change when retailers go multichannel is a dangerous one. Retailers leading the pack focus on providing a seamless and coherent experience across all channels, turning their traditional stores into "connected stores». Features and applications that originated online are entering the physical store. This allows new brands - including pure play retailers - without heritage in a market to seize an opportunity to leapfrog traditional players and become a household multi-channel brand.

Conclusions from this research and prospects for further developments in this area. Based on the results of the study, the factors in the diversification of consumer values are described. It is found that an important change in consumer attitudes is the trend toward the desire to be active co-creators instead of simply consumers and the customization of products in the market is graphically presented. Consumers' online risks are researched and analyzed and it is determined that trust also plays an important role in how consumers evaluate online security risks. The main existing digital retail trends are interpreted. It is justified that in the current situation in the market, when FMCG producers and traditional retailers, on the one hand, should launch new products faster, and on the other hand, maintain their high quality and achieve stable market results with them, it is advisable to prioritize four areas of their activity. The attitude of consumers to specialized retailers is investigated and analyzed. Considering the high competition between retailers and FMCG producers, it is recommended for them to conduct active marketing policies and implement relevant effective strategic decisions.

1. Chen, L. (2016). E-Retail Market Report. Deloitte, 42.

2. Oklander, M.A., Oklander, T.O., \& Yashkina, O.I. (2017). Tsyfrovyi marketynh - model marketynhu XXI storichchia [Digital Marketing - The Marketing Model of the 21st Century]. Oklander, M.A. (Ed.). Odesa [in Ukrainian].

3. Sabaitytė, J., Davidavičienė, V. (2018). The analysis of Internet marketing research directions. Marketynh i tsyfrovi tekhnolohii [Marketing and Digital Technologies], 2, 1, 7-20. Retrieved from http://mdt-opu.com.ua/index.php/mdt/article/view/25/27.

4. Nielsen. Official website. Retrieved from http://www.nielsen.com/ua/uk.html.

5. Deloitte. Official website. Retrieved from https://www2.deloitte.com/global/en.html.

6. Masayuki, A. \& Hitoshi, S. (2014). Shifting from consumption to experience. Winning in the omnichannel retailing. Retrieved from: http://www.ey.com/Publication/vwLUAssets/EY-Shifting-fromconsumer-to-experience/\$FILE/EY-Shifting-from-consumer-to-experience.pdf.

7. Schmitt, B. \& Rogers, D. (2011). Handbook on brand and experience management. Business collection, 328.

8. PWC. (2018). Global Consumer Insights Survey. Retrieved from https://www.pwc.com/gx/en/industries/consumer-markets/consumer-insights-survey.html.

9. PWC. (2018). Whom do Consumers really trust? Global Consumer Insights Survey. Retrieved from https://www.pwc.com/gx/en/retail-consumer/assets/consumer-trust-global-consumer-insightssurvey.pdf.

10. KPMG (2017). The truth about online consumers. Global Online Consumer Report. Retrieved from https://assets.kpmg.com/content/dam/kpmg/xx/pdf/2017/01/the-truth-about-online-consumers. pdf.

11. National Retail Association. Official website. Retrieved from: https://www.nra.net.au.

12. Kesteloo, M. \& Hoogenberg, M. (2018). Offline retail in an online world. PWC, 15.

13. World Economic Forum (2017). Shaping the Future of Retail for Consumer Industries. Insight Report. Retrieved from http://www3.weforum.org/docs/IP/2016/CO/WEF_AM17_ FutureofRetailInsightReport.pdf. 
A.О. Наторіна, канд. екон. наук, завідувач сектору навчальних закладів, відділ статистики і аналітики вищої освіти, ДНУ «Інститут освітньої аналітики» (Київ, Украӥна)

Діяльність ритейлерів та FMCG виробників у цифрову епоху

Досліджено та проаналізовано діяльність ритейлерів і FMCG виробників в умовах цифрової епохи базуючись на трунтовних результатах досліджень. Ідентифіковано напрями дієвого впливу на поведінку споживачів та інтерпретовано ключові аспекти діяльності ритейлерів, що дозволяють максимально задовольнити споживчі уподобання та впливають на їх поведінку. Детерміновано пріоритезовані сфери діяльності FMCG виробників на ринку. 3 огляду на інтенсивну конкуренцію між ритейлерами і FMCG виробниками, сформульовано релевантні рекомендації щңодо їх ефективного ринкового функиіонування, а також проведення активної маркетингової політики та імплементації ефективних стратегічних рішень.

Ключові слова: традиційні ритейлери, цифрові ритейлери, FMCG виробники, споживчі уподобання, споживча поведінка.

Received to the editor May 21, 2018 